\title{
KUALITAS LAPORAN KEUANGAN DAN PENCEGAHAN FRAUD DI PROVINSI KEPRI
}

\section{QUALITY OF FINANCIAL STATEMENTS AND PREVENTION OF FRAUD IN THE PROVINCE OF KEPRI}

\author{
Tumpal Manik ${ }^{1}$; Firmansyah Kusasi ${ }^{2}$ \\ 1 Universitas Maritim Raja Ali Haji - Tanjungpinang \\ 2Universitas Maritim Raja Ali Haji - Tanjungpinang \\ Email : tmanyk@gmail.com dan tmanik@umrah.ac.id
}

\begin{abstract}
ABSTRAK
Penelitian ini bertujuan untuk memberikan bukti empiris pengaruh kompetensi sumber daya manusia, penerapan standar akuntansi pemerintahan, pemanfatan teknologi informasi dan sistem pengendalian internal, terhadap kualitas laporan keuangan dengan pencegahan kecurangan (fraud) sebagai variabel pemoderasi. Populasi penelitian Satuan Kerja Perangkat Daerah (SKPD) atau sekarang disebut Organisasi Perangkat Daerah (OPD) yaitu pengelola unit kerja atau pejabat struktural pada Satuan Kerja Perangkat Daerah Provinsi Kepulauan Riau. Pengambilan data dengan penyebaran kuesioner sebanyak 250 respenden dan sebagai sampel data. Hasil penelitian menunjukkan bahwa variabel independen memiliki berpengaruh signifikan terhadap kualitas laporan keuangan antara lain penerapan standar akuntansi pemerintahan sebesar $27,9 \%$, pemanfatan teknologi informasi sebesar $8,7 \%$. sistem pengendalian internal sebesar $18,9 \%$ dan pencegahan kecurangan sebesar 4,88\% terhadap kualitas laporan keuangan. Sedangkan variabel pemoderasi pencegahan kecurangan sebagai pemoderasi memperkuat pengaruh penerapan standar akuntansi pemerintahan, penerapan teknologi informasi dan sistem pengendalian internal terhadap kualitas laporan keuangan.
\end{abstract}

Kata kunci : Pencegahan kecurangan dan kualitas laporan keuangan

\begin{abstract}
This study aims to provide empirical evidence of the influence of human resource competencies, application of government accounting standards, utilization of information technology and internal control systems, on the quality of financial statements by preventing fraud as a moderating variable. The research population of the Regional Work Unit (SKPD) or now called the Regional Apparatus Organization (OPD) is the manager of the work unit or structural official in the Riau Islands Regional Work Unit. Retrieval of data by distributing questionnaires as many as 250 Respendents and as a data sample. The results showed that the independent variable had a significant effect on the quality of financial statements including the application of government accounting standards by $27.9 \%$, utilization of information technology by $8.7 \%$. Internal control system at $18.9 \%$ and fraud prevention at $4.88 \%$ on the quality of financial statements. Whereas the moderating variable of fraud prevention as a moderating strengthens the effect of the application of government accounting standards, the application of information technology and internal control systems on the quality of financial statements.
\end{abstract}

Keywords : Prevention of fraud and the quality of financial statements 


\section{PENDAHULUAN}

Penyusunan laporan keuangan pemerintah berdasarkan standar akuntansi pemerintahan dan wajib memenuhi syarat normatif pelaporan agar laporan keuangan pemerintah dapat memenuhi laporan yang berkualitas yang dikehendaki yaitu: relevan, andal, dapat dibandingkan, dapat dipahami. Pola pertanggungjawaban laporan keuangan pemerintah daerah saat ini lebih bersifat horizontal (pemerintah daerah bertanggungjawab kepada DPRD maupun pada masyarakat). Pemerintah daerah diberikan wewenang untuk menyelenggarakan pengelolaan keuangannya sendiri. Selain adanya Standar Akuntansi Pemerintahan (SAP) yang sebagai pedoman dalam proses penyusunan laporan keuangan daerah, proses penyusunan laporan keuangan juga harus dilakukan secara efektif dan efisien, tepat waktu serta data-data yang dihasilkan dari laporan keuangan tersebut harus akurat.

Rendahnya kualitas laporan keuangan dapat disebabkan beberapa hal, misalnya kurangya pemahaman akuntansi pemerintahan dalam menyusunan laporan keuangan itu sendiri, belum diterapkannya secara optimal sistem informasi akuntansi keuangan daerah atau lemahnya peran internal audit. Dalam perkembangan kedepannya pemerintah daerah memerlukan perbaikan dalam hal meningkatkan kualitas laporan keuangan pemerintah daerah dengan mengurangi perlakuan praktik kecurangan akuntansi.

Apabila pada instansi pemerintah daerah kurang maksimal menyusun laporan keuangan, maka sistem informasi akuntansi pemerintahan tidak terlaksana dengan baik, khususnya pada saat pencatatan transaksi penggunaan angaran dan penyusunan laporan keuangan daerah yang akan berdampak pada keterambatan penyampaian laporan keuangan, sehingga hal ini dapat menimbulkan kurang maksimal informasi yang disajikan dalam laporan keuangan dan akan mengurangi kualitas laporan keuangan.

Beberapa hal yang perlu diperhatikan dalam menyusun laporan keuangan pemerintah daerah yang berkualitas, antara lain; kompetensi sumber daya manusia, penerapan standar akuntansi pemerintahan, pemanfatan teknologi informasi dan sistem pengendalian internal. Selain meningktakan kuaitas laporan keuangan, juga dapat mencegah agar tidak terjadi kecurangan (fraud). Berdasarkan teori ini, peneiti tertarik melakukan analisis penelitian bahwa kualitas laporan keuangan dipengaruhi beberapa faktor, yaitu kompetensi sumber daya manusia, sistem akuntansi keuangan daerah, sistem informasi akuntansi keuangan daerah, pemanfatan teknologi informasi, sistem penegendalian internal, hal ini dapat digunakan untuk mencegah kecurangan (fraud) menyusun lapaoran keuangan, maka berdasarkan terori ini peneliti tertarik meneliti dengan judul "kualitas laporan keuangan dan pencegahan fraud di Provinsi Kepri".

Penelitian diharapkan bermanfaat secara langsung dan tidak langsung terhadap berbagai pihak dalam pengembangan khasanah ilmu pengetahuan maupun dalam memecahkan masalah faktor - faktor yang mempengaruhi kualitas laporan keuangan dengan pencegahan fraud sebagai variabel pemoderasi. Variabel independen sebagai faktor-faktor yang mempengaruhi kualitas laporan keuangan adalah kompetensi sumber daya manusia, sistem akuntansi keuangan daerah, pemanfaatan teknologi informasi, sistem pengendalian intern, sedangkan varibel dependen adalah kualitas laporan keuangan dengan pencegahan fraud sebagai varibel pemoderasi.

Berdasarkan uraian ditas, maka tujuan peneitian ini adalah untuk memberikan bukti empiris 1) pengaruh kompetensi sumber daya manusia terhadap kualitas laporan keuangan, 2) pengaruh penerapan standar akuntansi pemerintahan terhadap kualitas laporan keuangan, 3) pengaruh pemanfatan teknologi informasi terhadap kualitas laporan keuangan dan 4) pengaruh sistem pengendalian internal terhadap kualitas laporan keuangan dan 5) pengaruh variabel independen terhadap kualitas laporan keuangan dengan pencegahan kecurangan sebagai variabel pemoderasi. 


\section{LANDASAN TEORI}

\section{Kualitas Laporan Keuangan Pemerintah Daerah}

Reformasi dibidang keuangan negara telah dilaksanakan melalui paket UndangUndang yang terdiri dari Undang-Undang Nomor 17 Tahun 2003 tentang Keuangan Negara, Undangundang Nomor 1 Tahun 2004 tentang Perbendaharaan Negara dan Undang-undang Nomor 15 Tahun 2004 tentang Pemeriksaan Pengelolaan dan Tanggungjawab Keuangan Negara. Ketiganya merupakan landasan dan pedoman agar keuangan negara dapat dikelola secara tertib, ekonomis, efisien, efektif, transparan dan bertanggung jawab dengan memperhatikan rasa keadilan dan kepatutan. Sejalan dengan tujuan tersebut, Undang-Undang nomor 28 tahun 2009 mengamanatkan untuk mewujudkan penyelenggaraan negara yang bebas dan bersih dari korupsi, kolusi dan nepotisme.

Standar Akuntansi Pemerintah (SAP) PP Tahun 2010 menyatakan karakteristik kualitatif laporan keuangan keuangan adalah ukuran-ukuran normatif yang perlu diwujudkan dalam informasi akuntansi sehingga dapat memenuhi tujuan. Keempat karakteristik tersebut merupakan persyaratan normatif yaitu relevan, andal, dapat dibandingkan dan dapat dipahami.

Pemerintah daerah diberikan wewenang untuk menyelenggarakan pengelolaan keuangannya sendiri. Selain adanya Standar Akuntansi Pemerintahan (SAP) yang sebagai pedoman dalam proses penyusunan laporan keuangan daerah, proses penyusunan laporan keuangan juga harus dilakukan secara efektif dan efisien, tepat waktu serta data-data yang dihasilkan dari laporan keuangan tersebut harus akurat, sesuai dengan prinsip-prinsip akuntansi yang diterapkan dalam menyusun dan menyajikan laporan keuangan pemerintah yaitu Standar Akuntansi Pemerintahan, sehingga pemahaman SAP sangat penting bagi para pegawai pemerintah daerah dalam pembuatan laporan keuangan daerah.

Menurut Halim (2002), laporan Keuangan Daerah merupakan informasi yang memuat data berbagai elemen struktur kekayaan dan struktur finansial yang merupakan pencerminan hasil aktivitas tertentu. Istilah Laporan Keuangan Pemerintah Daerah meliputi semua laporan dan berbagai penjelasannya yang mengakui laporannya tersebut akan diakui sebagai bagian dari laporan keuangan. Kualitas laporan keuangan diukur dengan indikator yaitu Aktivitas keuangan di masa lalu, Memprediksi masa yang akan dating, Ketepatwaktuan penyajian, Pengambilan keputusan, Disajikan wajar dan jujur, Informasi dapat dibandingkan Informasi dalam laporan keuangan dapat dipahami Sesuai SAP

Pemerintah sebagai pengemban amanat dari rakyat mempunyai kewajiban untuk melaksanakan tugasnya secara efektif dan efisien, salah satunya adalah mengelola keuangan negara dengan baik dan accountable. Namun, pada pelaksanaannya banyak praktik kecurangan yang berdampak negatif pada sektor ekonomi maupun sosial (Lediastuti, 2014). Salah satu indicator terjadinya permasalahan dalam pengelolaan keuangan instansi pemerintah juga dapat dilihat dari hasil pemeriksaan Badan Pemeriksa Keuangan terhadap laporan keuangan. Menurut Rendahnya kualitas laporan dapat disebabkan oleh belum diterapkanmya sistem informasi akuntansi keuangan atau kurangnya pemahaman akuntansi dari penyusun laporan keuangan itu sendiri atau kurangnya kompetensi sumber daya manusia yang dimiliki dan atau peran internal audit yang masih lemah (Setiowati., dkk, 2014).

Laporan keuangan yang berkualitas bukan hanya kelengkapan data dan informasi yang disajikan dalam laporan keuangan tersebut, melainkan termasuk pertanggungjawan semua informasi dalam laporan dan dapat dipertanggungjawabkan pada saat diverifikasi oleh pihak auditor dari Inspektorat maupun dari Badan Pemeriksa Keuangan (BPK). Kualitas laporan 
keuangan pemeritahan dinyatakan berkualitas apabila penyajian informasi dalam laporan keuangan tersebut telah memenuhi Standar Akuntansi Pemerintahan (SAP) yaitu prinsip-prinsip akuntansi yang diterapkan dalam menyusun dan menyajikan Laporan Keuangan Pemerintah, yang terdiri atas Laporan Keuangan Pemerintah Pusat (LKPP) dan Laporan Keuangan Pemerintah Daerah (LKPD), dalam rangka transparansi dan akuntabilitas penyelenggaraan akuntansi pemerintahan, serta peningkatan kualitas LKPP dan LKPD. SAP dinyatakan dalam bentuk Pernyataan Standar Akuntansi Pemerintahan (PSAP), yaitu SAP yang diberi judul, nomor, dan tanggal efektif. Selain itu, SAP juga dilengkapi dengan Kerangka Konseptual Akuntansi Pemerintahan. Standar Akuntansi Pemerintahan (SAP) ditetapkan dengan Peraturan Pemerintah No. 71 Tahun 2010 sebagai pengganti Peraturan Pemerintah No. 24 Tahun 2005. SAP dinyatakan dalam bentuk Pernyataan Standar Akuntansi Pemerintahan (PSAP), dilengkapi dengan Pengantar Standar Akuntansi Pemerintahan dan disusun mengacu kepada Kerangka Konseptual Akuntansi Pemerintahan. SAP harus digunakan sebagai acuan dalam menyusun laporan keuangan pemerintah, baik pemerintah pusat maupun pemerintah daerah.

\section{Pencegahan Kecurangan (Fraud)}

Fraud masih menjadi isu fenomenal dan menarik untuk dibahas dengan kasuskasus yang kini tengah berkembang dalam masyarakat. Association of Certified Fraud Examiners menggolongkan fraud dalam tiga jenis, yaitu kecurangan dalam laporan keuangan, penyalahgunaan asset dan korupsi (Surjandari, 2015). Salah satu jenis fraud yang paling sering terjadi di sektor pemerintahan yaitu berkaitan dengan praktik korupsi. Korupsi berasal dari bahasa latin, corruptio corrumpere yang artinya busuk, rusak, menggoyahkan, memutarbalik atau menyogok (Permana et al. 2017).

Fraud bisa dilakukan oleh siapa saja, meskipun pelaku fraud adalah orang yang baik dan dapat dipercaya. Apabila pelaku fraud tidak segera ditindak, maka kerugian perusahaan semakin besar dan memberi cerminan yang buruk bagi karyawan lain. Kemungkinan besar suatu kecurangan terjadi ketika lingkungan pekerjaan integritasnya lemah, pengendaliannya tidak kuat, kehilangan akuntabilitas, atau mendapat tekanan yang besar, maka tidak dapat dipungkiri seseorang akan melakukan ketidakjujuran. Tetapi, organisasi punya pilihan, mereka dapat membentuk lingkungan pekerjaan dimana kemungkinan terjadinya fraud sangat kecil, atau lingkungan pekerjaan yang brepeluang kemungkinan terjadinya fraud sangat besar.

Indonesia merupakan korupsi dengan total kerugian Negara sebesar Rp 1,47 Triliun (Indonesian Corruption Watch, 2017). Transparansi Internasional dalam surveynya tahun 2016 juga menunjukkan salah satu negara dengan tingkat korupsi yang tinggi. Data yang dihimpun oleh Indonesian Corruption Watch menunjukkan bahwa selama tahun 2016, terdapat 482 kasus bahwa Indonesia menempati peringkat 90 dari 176 negara yang diukur tingkat korupsinya dengan skor 37 (Transparency International 2016).

Tri, Novia (2018), strategi pencegahan fraud dalam pengelolaan keuangan menggunakan Analytical Hierarchy Process (AHP), bahwa strategi pencegahan fraud dalam pengelolaan keuangan pemerintah adalah: (1) perbaikan sistem pengawasan dan pengendalian, (2) meningkatkan kultur organisasi, (3) merumuskan nilai anti fraud, (4) menerapkan sistem reward dan punishment yang tegas, (5) sosialisasi anti fraud bagi pegawai, dan (6) membentuk agen perubahan.

Pencegahan kecurangan (fraud) merupakanupaya terintegrasi yang dapat menekan, terjadinya faktor penyebab fraud. (Pusdiklatwas BPKP, 2008:37) dan Amin Widjaja Tunggal 
(2012:59). Pencegarahan fraud dapat dianalisis berdasarkan : I) Budaya jujur dan etika yang tinggi: (1) Menetapkan tone at the top, (2) Menciptakan lingkungan kerja yang positif, (3) Mempekerjakan dan mempromosikan pegawai yang tepat, (4) Pelatihan, (5) Konfirmasi. II) Tanggung jawab manajemen untuk mengevaluasi pencegahan fraud: (1) Identifikasi risiko kecurangan, (2) Mengukur risiko kecurangan, (3) Mengurangi risiko kecurangan, (4) Memantau program pengendalian, III) Pengawasan oleh komite audit : (1) Pelaporan, (2) Laporan periodic, (3) Laporan lain. Pencegahan fraud merupakan upaya terintegrasi yang dapat menekan terjadinya faktor penyebab fraud (BPKP, 2010), antara lain: Penetapan kebijakan anti fraud, Komitmen melaksanakan kebijakan anti fraud yang ditetapkan, Prosedur pencegahan baku, Pemisahan fungsi, Media pendukung operasional, Evaluasi berkala.

Pengendalian internal yang terdapat dalam sebuah instansi atau organisasi tidak hanya mencakup kegiatan akuntansi dan keuangan saja tetapi meliputi segala aspek kegiatan organisasi tersebut. Tuanakotta (2012), menyatakan bahwa pengendalian internal merupakan langkah awal dalam pencegahan fraud. Pencegahan fraud pada umumnya adalah aktivitas yang dilaksanakan dalam halpenetapan kebijakan, sistem dan prosedur yang membantu bahwa tindakan yang diperlukan sudah dilakukan dewan komisaris, manajemen dan personil lain dalam perusahaan/organisasi untuk dapat memberikan keyakinan memadai dalam mencapai tujuan organisasiyaitu: efektivitas dan efisiensi operasi, keandalan laporan keuangan, dan kepatuhan terhadap hukum dan peraturan yang berlaku. Hasil penelitian Hermiyeti (2008), Nisak dkk., (2013), dan Purwitasari (2013) menyatakan bahwa pengendalian internal memiliki pengaruh signifikan terhadap pencegahan fraud. Hal tersebut menandakan bahwa perbaikan sistem pengendalian internal menjadi tolak ukur keberhasilan pencegahan fraud.

Beberapa starategi pencegahan fraud yang telah dilakukan pemerintah untuk mengendalikan perlakuan dan praktik korupsi, antara lain (1) Preventif, yaitu upaya mencegah, menangkal, dan mendeteksi fraud secara dini melalui serangkaian kegiatan, (2) Investigatif, yaitu segera mendeteksi, mengungkap fakta kejadian, dan menindaklanjuti sesuai ketentuan, (3). Edukatif, yaitu upaya meningkatkan kepedulian individu di dalam dan di luar organisasi untuk mendorong peran serta memerangi fraud. Pencegahan merupakan bagian dari sistem pengendalian Fraud yang memuat langkah-langkah dalam rangka mengurangi potensi risiko terjadinya Fraud, yang paling kurang mencakup fraud awareness, identifikasi kerawanan dan know your employee.

\section{Kompetensi Sumber Daya Manusia}

Kompetensi Sumber Daya Manusia (SDM) merupakan potensi yang terkandung dalam diri manusia untuk mewujudkan peranannya sebagai manusia yang adaptif dan transformatif yang mampu mengelola dirinya sendiri serta seluruh potensi yang terkandung di alam menuju tercapainya kesejahteraan kehidupan dalam tatanan yang seimbang dan berkelanjutan. Sumber daya manusia adalah faktor penting demi terciptanya laporan keuangan yang berkualitas. Keberhasilan suatu entitas bukan hanya dipengaruhi oleh Sumber Daya Manusia yang dimilikinya melainkan kompetensi sumber daya manusia yang dimilikinya. Dalam hal ini kompetensi sumber daya manusia memiliki peranan yang sangat penting untuk merencanakan, melaksanakan, dan mengendalikan entitas yangbersangkutan.

Kompetensi menurut Guy et al. (2002), adalah pengetahuan dan keahlian yang diperlukan untuk menyelesaikan tugas. Variabel bebas kompetensi sumber daya manusia menggukan item 7 item pertanyaan dengan skala likert 1-5, diukur dengan indikator : pemahaman tentang akuntansi, SDM yang berkualitas, Sumber daya yang memadai, Peran dan tanggung jawab, 
Pelatihan keahlian dalam tugas, Sosialisasi peraturan baru dan Pemahaman tentang struktur organisasi. Berdasarkn teori diatas, maka hipotesis yang dikembangkan adalah :

H1 : Kompetensi sumberdaya manusia berpengaruh terhadap pengcegahan fraud H5 : Kompetensi sumberdaya manusia berpengaruh terhadap kualitas laporan keuangan H10 : Kompetensi sumberdaya manusia berpengaruh terhadap kualitas laporan keuangan yang dimoderasi dengan variable pengcegahan fraud

\section{Penerapan Sistem Akuntansi Pemerintahan Keuangan Daerah}

Badan Akuntansi Keuangan Negara (BAKUN) Departemen Keuangan RI (2001:1), Sistem akuntansi keuangan secara sederhana adalah suatu sistem informasi yang menggabungkan proses pencatatan, pengklasifikasian, pengikhtisaran, pelaporan data yang berkaitan dengan keuangan dari suatu entitas sehingga dapat menghasilkan informasi keuangan yang dapat digunakan sebagai dasar dalam pengambilan keputusan oleh pihak-pihak yang berkepentingan, yakni kesesuaian sistem dengan SAP, pengidentifikasian transaksi, pencatatan transaksi, bukti disetiap transaksi, pencatatan kronologis, pengklasifikasian transaksi, laporan keuangan setiap periode dan pelaporan yang konsisten dan periodik.

Menurut permendagri Nomor 13 Tahun 2006 pasal 233 ayat (1), bahwa sistem Akuntansi Pemerintahan Daerah sekurang-kurangnya meliputi: prosedur akuntansi penerimaan kas, prosedur pengeluaran kas, prosedur akuntansi aset tetap/barang milik daerah, dan prosedur akuntansi selain kas. a) Prosedur akuntansi penerimaan kas meliputi serangkaian proses baik manual maupun terkomputerisasi mulai dari pencatatan, pengikhtisaran atas transaksi dan kejadian keuangan serta pelaporan keuangan, b) Prosedur akuntansi pengeluaran kas meliputi serangkaian prosedur baik manual maupun terkomputerisasi mulai dari pencatatan, pengikhtisaran atas dasar pertanggungjawaban, c) Prosedur akuntansi aset tetap meliputi pencatatan dan pelaporan akuntansi atas perolehan, pemeliharaan, rehabilitasi, perubahan klarifikasi, dan penyusunan terhadap aset tetap, d). Prosedur Akuntansi selain kas prosedur akuntansi selain kas meliputi serangkaian proses baik manual maupun komputerisasi mulai dari pencatatan, pengikhtisaran atas transaksi dan kejadian keuangan dalam rangka pertanggungjawaban pelaksanaan APBD.

Penyusunan laporan keuangan yang berpedoman pada standar akuntansi pemerintah sesungguhnya dalam rangka peningkatan kualiats laporan keuangan, sehingga laporan keuangan yang dimaksud dapat meningkatkan kredibilitasnya dapat mewujudkan transparansi dan akuntabilitas pengelolaan keuangan. Permendagri Nomor 64 Tahun 2013, pasal 5 menegaskan bahwa Sitem Akuntansi Pemerintahan Daerah memuat pilihan prosedur dan teknik akuntansi dalam melakukan identifikasi transaksi, pencatatan pada jurnal, posting kedalam buku besar, penyusunan neraca saldo serta penyajian laporan keuangan. Penyajian laporan keuangan sebagaimana dimaksud terdiri atas: a) laporan realisasi anggaran, b) laporan perubahan saldo anggaran lebih, c) neraca, d) laporan operasional, e) laporan arus kas, f) laporan perubahan ekuitas, dan g) catatan atas laporan keuangan. Berdasarkn teori diatas, maka hipotesis yang dikembangkan adalah:

H2: Penerapan sistem akuntansi pemerintahan berpengaruh terhadap pengcegahan fraud

H6 : Penerapan sistem akuntansi pemerintahan berpengaruh terhadap kualitas laporan keuangan

H11: Penerapan sistem akuntansi pemerintahan berpengaruh terhadap kualitas laporan keuangan yang dimoderasi dengan variable pengcegahan fraud 


\section{Pemanfaatan Teknologi Informasi}

Pemanfaatan teknologi informasi merupakan penggunaan secara optimal dari komputer (mainframe, mini, micro), perangkat lunak (software), database, jaringan (internet, intranet), electronic commerce, dan jenis lainnya yang berhubungan dengan teknologi (Wilkinson et al., 2000). Pemanfaatan teknologi informasi mencakup adanya a) pengolahan data, pengolahan informasi, sistem manajemen dan proses kerja secara elektronik dan b) pemanfaatan kemajuan teknologi informasi agar pelayanan publik dapat diakses secara mudah dan murah oleh masyarakat (Hamzah, 2009).

Keputusan dari hasil pemrosesan teknologi komputer ke dalam sistem informasi akuntansi keuangan, telah mengubah cara kerja para pegawai pada posisi keuangan dan akuntansi, yaitu dalam penyimpanan data, pengambilan kembali data, dan pengendalian hanya melalui komputer. Data yang tersimpan dalam komputer akan memudahkan proses audit teknologi informasi (Audit EDP), dimana proses audit electronic data processing terdapat tiga cara digunakan dalam melaksanakan prosedur audit dengan menggunakan komputer antara lain: pemroses data pengujian auditor pada sistem komputer klien sebagai bagian dari pengujian pengendalian, menguji pembukuan yang diselenggarakan komputer sebagai sarana untuk melakukan verifikasi atas laporan keuangan klien, menggunakan komputer untuk melaksanakan tugas audit yang terpisah dari catatan klien (Manik, 2018). Berdasarkn teori diatas, maka hipotesis yang dikembangkan adalah :

H3 : Pemanfaatan teknologi informasi berpengaruh terhadap pengcegahan fraud H7 : Pemanfaatan teknologi informasi berpengaruh terhadap kualitas laporan keuangan H12: Pemanfaatan teknologi informasi berpengaruh terhadap kualitas laporan keuangan yang dimoderasi dengan variable pengcegahan fraud

\section{Sistem Pengendalian Intern}

Sistem Pengendalian Intern (SPI) merupakan suatu cara untuk mengarahkan, mengawasi, dan mengukur sumber daya suatu organisasi, serta berperan penting dalam pencegahan dan pendeteksian penggelapan (fraud). Pengendalian intern terdiri atas kebijakan dan prosedur yang digunakan dalam mencapai sasaran dan menjamin atau menyediakan informasi keuangan yang andal, serta menjamin ditaatinya hukum dan peraturan yang berlaku. Variabel sistem pengendalian intern diukur dengan indikator yaitu: Standard Operating Procedure (SOP), Implementasi PP № 60, Dokumen dan catatan yang memadai, Pemisahan wewenang, Tindakan disiplin atas pelanggaran

Fadilah (2011), menyatakan bahwa sistem pengendalian internal memiliki pengaruh langsung terhadap Good Governance sehingga berimplikasi terhadap pencegahan fraud. Namun, sistem pengendalian internal tidak luput dari kelemahannya, kelemahan ini dapat dimanfaatkan oleh oknum pelaku kecurangan (Martani dan Zaelani, 2011). Jika kelemahan sistem ini didukung oleh moralitas aparatur yang baik, maka segala jenis kecurangan dapat dicegah, seperti hasil penelitian dari Salindeho (2012), menyatakan bahwa moralitas aparatur pemerint ahan yang dinyatakan dalam etika pemerintah memiliki pengaruh yang kuat terhadap kinerja pemerintahan tersebut. Berdasarkn teori diatas, maka hipotesis yang dikembangkan adalah :

H4 : Sistem pengendalian intern berpengaruh terhadap pengcegahan fraud H8 : Sistem pengendalian intern berpengaruh terhadap kualitas laporan keuangan H13: Sistem pengendalian intern berpengaruh terhadap kualitas laporan keuangan yang dimoderasi dengan variable pengcegahan fraud 


\section{METODOLOGI PENELITIAN}

\section{Jenis dan Spesifikasi Penelitian}

Jenis penelitian ini menggunakan metode kualitatif dan kuantitatif. Pendekatan metode kualitatif untuk memperoleh pemahaman makna penelitian, menyajikan data apa-adanya serta menginterpretasikan korelasi sebagai faktor melalui berbagai sudut pandang atau proses pengambilan data dari kondisi yang sedang berlangsung dengan maksud untuk mencari, menemukan dan menyusun analisis faktor - faktor yang mempengaruhi kualitas laporan keuangan dengan pencegahan fraud sebagai variabel pemoderasi di Provinsi Kepulauan Riau,

\section{Lokasi Tempat dan Waktu Penelitian}

Penelitian ini memilih lokasi Provinsi Kepulauan Riau karena Pemerintah Daerah Provinsi Kepulauan Riau sebagai pusat alokasi anggaran Pemerintahan daerah Provinsi Kepulauan Riau dapat mewakili wilayah Kabupaten dan Kota lainnya sesuai dengan objek pengamatan pada Kualitas Laporan Keuangan Dengan Pencegahan Fraud. Waktu proses pelaksanaan penelitian dilakukan selama 8 (delapan) bulan, yaitu mulai Maret - Oktober 2018, sesuai periode pengajuan penelitian internal UMRAH Skema Kompetitif Unggulan Perguruan Tinggi

\section{Populasi dan Sampel}

Populasi adalah wilayah generalisasi yang terdiri dari objek atau subjek yang akan menjadi kuantitas dan karakteristik tertentu yang ditetapkan oleh penelitian untuk dipelajari dan kemudian ditarik kesimpulannya (Sugiono, 2012). Populasi dalam penelitian ini adalah Satuan Kerja Perangkat Daerah (SKPD) atau sekarang disebut Organisasi Perangkat Daerah (OPD) yaitu pengelola unit kerja atau pejabat struktural pada Satuan Kerja Perangkat Daerah Provinsi Kepulauan Riau. Populasi penelitian ini memiliki kriteri untuk pengambilan sampel yakni hanya pada Kantor Dinas/Badan memiliki anggaran yang telah disepakati > 20 miliar, maka jumlah sampel adalah 250 Orang Respenden.

\section{Teknik Pengumpulan Data}

Tujuan teknik pengumpulan data dilakukan peneliti adalah untuk melengkapi informasi dan sumber data-data yang dibutuhkan selama pengolahan data-data penelitian, baik data utama maupun data pendukung yakni data yang bersifat primer maupun sekunder, maka teknik pengumpulan data, antara lain; 1) Observasi; Observasi merupakan salah satu teknik pengumpulan data yang tidak hanya mengukur sikap dari responden (wawancara dan angket) namun juga dapat digunakan untuk merekam berbagai fenomena yang terjadi (situasi, kondisi). Dalam observasi ini, peneliti secara langsung terlibat dalam kegiatan sehari-hari orang atau situasi yang diamati sebagai sumber data, 2) Angket/kuisioner; Angket/kuesioner adalah teknik pengumpulan data yang dilakukan dengan cara memberikan seperangkat pertanyaan atau pernyataan kepada orang lain yang dijadikan responden untuk dijawab, tujuan pertanyaan yang diberikan kepada responden untuk menggali data sesuai dengan rumusan masalah dan tujuan penelitian, 3) Wawancara; Wawancara merupakan teknik pengumpulan data yang dilakukan melalui tatap muka dan tanyajawab langsung antara pengumpul data maupun peneliti terhadap narasumber atau sumber data, 4) Studi Kepustakaan; suatu bentuk pengumpulan data melalui buku yang sesuai dengan penelian atau literatur, hasil penelitian terdahulu. 


\section{Variabel Penelitian dan Definisi Operasional Variabel}

Variabel adalah apapun yang dapat membedakan atau membawa variasi pada suatu nilai. Dalam penelitian ini menggunakan tiga bentuk variabel penelitian, antara lain : 1) Variabel Independen yakni Kompetensi Sumber Daya Manusia (X1), Penerapatan Satandar Akuntansi Pemerintahan (X2), Pemanfatan Teknologi Informasi (X3) dan Sistem Penegendalian Internal (X4). Variabel Depeneden/terikat yaitu Kualitas Laporan Keuangan (Y) dan Variabel Pemoderasi yakni Pencegahan Fraud (Z).

Variabel Kompetensi Sumber Daya Manusia, Penerapan Standar Akuntansi Pemerintahan, Pemanfaatan Teknologi Informasi dan Sistem Pengendalian Intern masingmasing variabel diukur dengan model skala Likert lima poin, yaitu (1) Sangat Tidak Setuju, (2) Tidak Setuju, (3) Ragu-Ragu, (4) Setuju, dan (5) Sangat Setuju. Responden diminta untuk menyatakan menyatakan setuju atau ketidaksetujuannya terhadap pertanyaan yang diajukan sesuai dengan kondisi mereka yang sesungguhnya. Skala pengukuran dalam penelitian ini menggunakan skala interval. Skala interval merupakan skala pengukuran yang mempunyai selisih sama antara satu pengukuran dengan pengukuran yang lain. Data yang diperoleh dari skala Likert adalah berupa data interval, karena skala Likert menggunakan lima angka penilaian, yaitu skor 1 untuk pernyataan sangat tidak setuju, skor 2 untuk pernyataan tidak setuju, skor 3 untuk pernyataan netral, skor 4 untuk pernyataan setuju, dan skor 5 untuk pernyataan sangat setuju.

\section{Variabel Terikat (Dependent Variable)}

Variabel terikat $(Y)$ dalam penelitin ini adalah Kualitas laporan keuangan, Penelitian ini ingin mengetahui kualitas laporan keuangan sesauai dengan penggunaan anggaran yang telah disetujui. Variabel terikat (dependent variable). Indikator Variabel Kualitas Laporan Keuangan terdiri dari; 1) Mengunajkan acuan standar akuntansi pemerintahan, 2) Laporan keuangan disajikan dengan andal dan dapat dipercaya, 3) Informasi laporan keuangan yang disajikan dapat dipahami dan jelas, 4) Informasi dalam laporan keuangan dapat dibandingkan, 5) pedoman penyusunan LKPD, 6) Laporan keungan yang transparan dan bertanggungjawab, 7) taat pada peraturan perundang-undangan dan 8) tepat waktu untuk Penetapan Perda APBD.

\section{Variabel Pemoderasi (Moderating Variable)}

Variabel dependent/terikat (Z) yang digunakan dalam penelitian ini adalah Pencegahan Kecurangan (Fraud). Fraud dapat didefenisikan sebagai suatu penyimpangan atau perbuatan melanggar hokum (IIlegal Acts) yang dilakukan dengan sengaja, utuk tujuan tertentu, keuntungan pribadi atau kelompok secara tidak fair baik secara langsung maupun tidak langsung merugikan pihak lain yang disengaja dengan cara tidak jujur atau melawan hukum (Tuannakotta, 2014:96). Indikator varibel fraud terdiri dari; 1) Sosialisasi perundang-undangan mencegah kecurangan, 2) menetapkan kebijakan anti fraud, 3) menetapkan prosedur penanganan pencegahan fraud, 4) melaksanakan kebijakan anti fraud/kecurangan, 5) melaksanakan pembagian tugas yang jelas, 6) menindak pelaku fraud, 7) Kualitas perundang-undangan anti fraud, 8) kinerja yang jelas.

\section{Variabel Bebas (Independent Variable)}

Variabel independent dalam penelitian ini terdiri dari; kompetensi sumber daya manusia, penerapan sistem akuntansi pemerintah daerah, pemanfaatan teknologi informasi, dan sistem pengendalian intern.

1. Kompetensi Sumber Daya Manusia (SDM) merupakan potensi yang terkandung dalam diri manusia untuk mewujudkan peranannya sebagai manusia yang adaptif dan transformatif 
yang mampu mengelola dirinya sendiri serta seluruh potensi yang terkandung di alam menuju tercapainya kesejahteraan kehidupan dalam tatanan yang seimbang dan berkelanjutan. Indikator kompetensi SDM; 1) latar belakang pendidikan bagian keuangan dan akuntansi, 2) memahami standar akuntansi pemerintahan, 3) menyelesaikan tugas dengan tepat waktu, 4) kesalahan laporan yang dilakukan seorang pegawai, 5) pelatihan, 6) sosialisasi tentang UU, 7) Menyampaikan laporan keuangan tepat waktu, 8)

2. Penerapan Sistem Akuntansi Pemerintahan Keuangan Daerah; Badan Akuntansi Keuangan Negara (BAKUN) Departemen Keuangan RI (2001:1), Sistem akuntansi keuangan secara sederhana adalah suatu sistem informasi yang menggabungkan proses pencatatan, pengklasifikasian, pengikhtisaran, pelaporan data yang berkaitan dengan keuangan dari suatu entitas sehingga dapat menghasilkan informasi keuangan yang dapat digunakan sebagai dasar dalam pengambilan keputusan oleh pihak-pihak yang berkepentingan. indikator penerapan sistem akuntansi pemerintahan keuangan daerah terdiri dari; 1) Laporan Keuangan disusun/disajikan sebagai bentuk pertanggungjawaban, 2) pengguna laporan keuangan untuk mengevaluasi pelaksanaan kegiatan suatu entitas, 3) Laporan Keuangan disusun/disajikan memberikan informasi keuangan yang terbuka dan jujur, 4) laporan keuangan mengetahui kecukupan penerimaan pada periode pelaporan, 5) Laporan Keuangan disusun/disajikan dapat menilai derajat pencapaian.

3. Pemanfaatan Teknologi Informasi; merupakan penggunaan secara optimal dari komputer (mainframe, mini, micro), perangkat lunak (software), database, jaringan (internet, intranet), electronic commerce, dan jenis lainnya yang berhubungan dengan teknologi (Wilkinson et al., 2000). Indikator pemanfaatan teknologi informasi terdiri dari; 1) sistem informasi yang terintegrasi lebih cepat, mudah dan akurat, 2) Jaringan internet dan komputer dimanfaatkan sebagai penghubung dalam pengiriman informasi, 3) Proses akuntansi dan pelaporan dilakukan secara komputerisasi, 4) pengelola keuangan memiliki komputer dengan jumlah yang cukup, 5) Jadwal pemeliharaan peralatan secara teratur dan tepat.

4. Sistem Pengendalian Intern (SPI) merupakan suatu cara untuk mengarahkan, mengawasi, dan mengukur sumber daya suatu organisasi, serta berperan penting dalam pencegahan dan pendeteksian penggelapan (fraud). Pengendalian intern terdiri atas kebijakan dan prosedur yang digunakan dalam mencapai sasaran dan menjamin atau menyediakan informasi keuangan yang andal, serta menjamin ditaatinya hukum dan peraturan yang berlaku. Indikator Sistem Pengendalian Internal terdiri dari; 1) Integritas data dan dokumen tersimpan dengan baik, 2) mencatat transaksi keuangan dengan memposting secara tepat, 3) Transaksi tidak dapat dilakukan tanpa adanya otorisasi dari pihak yang berwenang, 4) kualitas personal bagian pengendalian internal, 5) SKPD/OPD mempunyai struktur organisasi dan uraian tugas, 6) pembagian wewenang dan tanggungjawab yang jelas, 7) otorisasi transaksi harus dilaksanakan dan bukti pendukung, 8) diterapkan peraturan untuk dilakukannya pemantauan dan evaluasi atas aktivitas operasional.

\section{Pengolahan Data dan Pengujian Penelitian}

Salah satu syarat untuk bisa menggunakan persamaan regresi berganda adalah terpenuhinya uji asumsi klasik. Empat uji asumsi klasik dalam penelitian ini meliputi normalitas, asumsi heteroskedastisitas, autokorelasi dan multikolinearitas. Kemudian pengujian hipotesis dan uji varibel pemoderasi melalui uji-t, uji-f dan uji determinasi. 


\section{HASIL DAN PEMBAHASAN}

Pengujian Pengaruh Kompetensi SDM, Penerapan SAP, Pemanfatan TI dan Sistem PI terhadap Pencegahan Kecurangan.

Hasil pengujian penelitian Pengaruh Kompetensi SDM, Penerapan SAP, Pemanfatan TI dan Sistem PI terhadap Pencegahan Kecurangan secara parsial dan simultan ditunjukkan dalam tabel dibawah ini.

Tabel 1. Pengujian Secara Parsial

Pengaruh Kompetensi SDM, Penerapan SAP, Pemanfatan TI dan Sistem PI terhadap Pencegahan Kecurangan

\begin{tabular}{lcccc}
\hline Variable & $\begin{array}{c}\text { Unstandardized } \\
\text { Coefficients }\end{array}$ & $\begin{array}{c}\text { Standardized } \\
\text { Coefficients }\end{array}$ & T-Test & $\begin{array}{c}\text { Probability } \\
\text { (Sig. a 0,05) }\end{array}$ \\
\hline (Constant) & 4,140 & & 3.073 & 0,002 \\
\hline Kompetensi SDM (KSDM) & 0,115 & 0,100 & 2.178 & 0,030 \\
\hline Penerapan SAP (PSAP) & 0,288 & 0,436 & 10.094 & 0,000 \\
\hline Pemanfatan TI (PTI) & 0,067 & 0,069 & 1.559 & 0,120 \\
\hline Sistem PI (SPI) & 0,440 & 0,488 & 10.429 & 0,000 \\
\hline R Square & & & & 0,566 \\
Adjusted R Square & & & & 0,559 \\
F-Test & & & & 79.980 \\
Probability & & & & 0,000 \\
\hline
\end{tabular}

a. Dependent Variable: Pencegahan Kecurangan

b. Predictors: (Constant), Kompetensi SDM, Penerapan SAP, Pemanfatan TI, Sistem PI.

Sumber data kuesioner, diolah dengan aplikasi SPSS V.24, (2019)

Tabel.1 diatas menunjukkan bahwa beberapa variabel independen berpengaruah signifikan terhadap variabel pencegahan kecurangan, hasil pengujian diformulasikan dalam regresi berganda dari pengujian tabel 1 secara parsial sebagai berikut :

$$
\begin{aligned}
& \mathrm{Y} 1=\beta 0+\beta 1 \mathrm{KSDM}+\beta 2 \mathrm{PSAP}+\beta 3 \mathrm{PTI}+\beta 4 \mathrm{SPI}+\varepsilon \\
& \mathrm{Y} 1=4,140+0,115 \mathrm{KSDM}+0,288 \mathrm{PSAP}+0,067 \mathrm{PTI}+0,440 \mathrm{SPI}+\varepsilon
\end{aligned}
$$

Berdasarkan tabel 1 diatas, menunjukkan bahwa interpretasi hasil penelitian sesaui dengan tujuan penelitian ini adalah :

KSDM Kualitas Sumber Daya Manusia (KSDM) memberikan koefisien parameter 0,115 dengan tingkat signifikansi (a) yakni 0,030 <0,05, hipotesis menunjukkan bahwa kualitas sumber daya manusia berpengaruh signifikan terhadap pencegahan kecurangan. Artinya setiap peningkatan kualitas sumber daya manusia akan meningkatkan pencegahan kecurangan sebesar $11,5 \%$.

PSAP Penerapan Standar Akuntansi Pemerintahan (PSAP) berpengaruh signifikan terhadap pencegahan kecurangan, pada tingkat 0,05 $(0,000<0,05$, tingkat kepercayaan 95\%), koefisen regesi sebesar 0,288 . Artinya setiap peningkatan penggunaan/penerapan standar akuntansi pemerintahan dalam menyusun laporan keuangan pemerintahan daerah Kepri akan meningkatkan pencegahan kecurangan sebesar $28,8 \%$. 
PTI Pemanfatan Teknologi Informasi (PTI) berpengaruh signifikan terhadap pencegahan kecurangan, pada tingkat 0,05 $(0,020<0,05$, tingkat kepercayaan 95\%), koefisen regesi sebesar 0,067 . Artinya setiap peningkatan penggunaan dan pemanfatan teknologi informasi akuntansi pemerintahan dalam menyusun laporan keuangan pemerintahan daerah Kepri akan meningkatkan pencegahan kecurangan sebesar 6,7\%.

SPI Sistem pengendalian Internal (SPI) berpengaruh signifikan terhadap pencegahan kecurangan, pada tingkat 0,05 $(0,000<0,05$, tingkat kepercayaan 95\%), koefisen regesi sebesar 0,440. Artinya setiap penerapan sistem pengendalian internal dalam penggunaan anggaran pemerintahan daerah Kepri akan meningkatkan pencegahan kecurangan sebesar $4,40 \%$.

Pengujian secara simultan Uji-F variabel kompetensi sumber daya manusia, penerapan standar akuntansi pemerintahan, pemanfatan teknologi informasi dan sistem pengendalian internal berpengaruh signifikan terhadap pencegahan kecurangan, pada tingkat 0,05 $(0,000<$ 0,05 , tingkat kepercayaan 95\%), dengan nilai adjust $R$ Square sebesar 0,559. Artinya secara parsial variabel (kompetensi sumber daya manusia, penerapan standar akuntansi pemerintahan, pemanfatan teknologi informasi dan sistem pengendalian internal) memiliki pengaruh sebesar $55,9 \%$ terhadap pencegahan kecurangan, sedangan pengaruh lainnya sebesar $44,10 \%$ diluar variabel penelitian ini.

\section{Pengujian Pengaruh Kompetensi SDM, Penerapan SAP, Pemanfatan TI dan Sistem PI, Pencegahan Kecurangan terhadap Kualitas Laporan Keuangan}

Hasil pengujian penelitian menunjukkan bahwa beberapa varabel bebas berpengaruh signifikan terhadap kualitas laporan keuangan, selain variabel Kompetensi SDM yang tidak berpengaruh signifikan ditunjukkan dalam tabel dibawah ini.

Tabel 2. Pengujian Secara Parsial

Pengaruh Kompetensi SDM, Penerapan SAP, Pemanfatan TI dan Sistem PI Pencegahan Kecurangan terhadap Kualitas Laporan Keuangan

\begin{tabular}{lcccc}
\hline Variable & $\begin{array}{c}\text { Unstandardized } \\
\text { Coefficients }\end{array}$ & $\begin{array}{c}\text { Standardized } \\
\text { Coefficients }\end{array}$ & T-Test & $\begin{array}{c}\text { Probabilitas } \\
\text { (Sig. a 0,05) }\end{array}$ \\
\hline (Constant) & $-0,966$ & & $-0,758$ & 0,449 \\
\hline Kompetensi SDM (KSDM) & 0,005 & 0,004 & 0,100 & 0,921 \\
\hline Penerapan SAP (PSAP) & 0,279 & 0,421 & 11.377 & 0,000 \\
\hline Pemanfatan TI (PTI) & 0,087 & 0,089 & 2.342 & 0,020 \\
\hline Sistem PI (SPI) & 0,189 & 0,209 & 4.215 & 0,000 \\
\hline Penceg. Kecurangan (PKC) & 0,488 & 0,471 & 9.460 & 0,000 \\
\hline R Square & & & & 0,683 \\
Adjusted R Square & & & & 0,676 \\
F-Test & & & & 104.994 \\
Probability & & & & 0,000 \\
\hline
\end{tabular}

a. Dependent Variable: Kualitas Laporan Keuangan

b. Predictors: (Constant), Kompetensi SDM, Penerapan SAP,

Pemanfatan TI, Sistem PI, Pencegahan Kecurangan

Sumber data kuesioner, diolah dengan aplikasi SPSS V.24, (2019) 
Tabel.2 diatas menunjukkan bahwa beberapa variabel independen berpengaruah signifikan terhadap variabel Kualitas Laporan Keuangan, hasil pengujian diformulasikan dalam regresi berganda dari pengujian tabel 1 secara parsial sebagai berikut :

\section{$\mathrm{Y} 2=\beta 0+\beta 1 \mathrm{KSDM}+\beta 2 \mathrm{PSAP}+\beta 3 \mathrm{PTI}+\beta 4 \mathrm{SPI}+\beta 5 \mathrm{PKC}+\varepsilon$ \\ $\mathrm{Y} 2=-0,966+0,005 \mathrm{KSDM}+0,279 \mathrm{PSAP}+0,087 \mathrm{PTI}+0,189 \mathrm{SPI}+0,488 \mathrm{PKC}+\varepsilon$}

Berdasarkan tabel 2 di atas, menunjukkan bahwa interpretasi hasil penelitian sesaui dengan tujuan penelitian ini adalah :

KSDM Kualitas Sumber Daya Manusia (KSDM) memberikan koefisien parameter 0,005 dengan tingkat signifikansi (a) yakni 0,921 >0,05, hipotesis menunjukkan bahwa kualitas sumber daya manusia tidak berpengaruh signifikan terhadap kualitas laporan keuangan. Artinya kualitas sumber daya manusia belum menunjukkan yang mempengaruhi kualitas laporan keuangan.

PSAP Penerapan Standar Akuntansi Pemerintahan (PSAP) berpengaruh signifikan terhadap kualitas laporan keuangan, pada tingkat $0,05(0,000<0,05$, tingkat kepercayaan $95 \%)$, artinya setiap peningkatan penggunaan/penerapan Standar Akuntansi Pemerintahan dalam menyusun laporan keuangan pemerintahan daerah Kepri akan meningkatkan kualitas laporan keuangan sebesar 27,9\%.

PTI Pemanfatan Teknologi Informasi (PTI) berpengaruh signifikan terhadap kualitas laporan keuangan, pada tingkat $0,05(0,020<0,05$, tingkat kepercayaan $95 \%)$, artinya setiap peningkatan penggunaan dan pemanfatan teknologi informasi akuntansi pemerintahan dalam menyusun laporan keuangan pemerintahan daerah Kepri akan meningkatkan kualitas laporan keuangan sebesar 8,7\%.

SPI Sistem pengendalian Internal (SPI) berpengaruh signifikan terhadap kualitas laporan keuangan, pada tingkat $0,05(0,000<0,05$, tingkat kepercayaan $95 \%)$, artinya setiap penerapan sistem pengendalian internal dalam penggunaan anggaran pemerintahan daerah Kepri akan meningkatkan kualitas laporan keuangan sebesar 18,9 \%.

PKC Pencegahan Kecurangan (PKC) berpengaruh signifikan terhadap kualitas laporan keuangan, pada tingkat $0,05(0,000<0,05$, tingkat kepercayaan $95 \%)$, artinya setiap adanya kontrol dan monitoring pencegahan kecurangan akuntansi dalam penggunaan anggaran pemerintahan daerah Kepri akan meningkatkan kualitas laporan keuangan sebesar $4,88 \%$.

Pengujian secara simultan Uji-F variabel kompetensi sumber daya manusia, penerapan standar akuntansi pemerintahan, pemanfatan teknologi informasi, sistem pengendalian internal dan pencegahan kecurangan berpengaruh signifikan terhadap pencegahan kecurangan, pada tingkat $0,05(0,000<0,05$, tingkat kepercayaan 95\%), dengan nilai adjust $R$ Square sebesar 0,676 . Artinya secara parsial variabel (kompetensi sumber daya manusia, penerapan standar akuntansi pemerintahan, pemanfatan teknologi informasi, sistem pengendalian internal dan 0,676) memiliki pengaruh sebesar $67,6 \%$ terhadap kualitas laporan keuangan, sedangan pengaruh lainnya sebesar $32,3 \%$ diluar variabel penelitian ini. 


\section{Pengujian Moderasi}

Hasil pengujian variabel moderasi Pencegahan Kecurangan $(Z)$ terhadap kualitas laporan keuangan menunjukkan bebereapa variabel sebagai pemoderasi di tunjukkan dalam tabel 3 dibawah ini

Tabel 3. Pengujian Moderasi

\begin{tabular}{lcccc}
\hline Variable & $\begin{array}{c}\text { Unstandardized } \\
\text { Coefficients }\end{array}$ & $\begin{array}{c}\text { Standardized } \\
\text { Coefficients }\end{array}$ & T-Test & $\begin{array}{c}\text { Probabilitas } \\
\text { (Sig. a 0,05) }\end{array}$ \\
\hline (Constant) & 10.905 & & 16.639 & 0,000 \\
\hline Moderasi 1 (KSDM x PKC) & 0,000 & 0,011 & 0,202 & 0,840 \\
\hline Moderasi 2 (PSAP x PKC) & 0,011 & 0,521 & 11.831 & 0,000 \\
\hline Moderasi 3 (PTI x PKC) & 0,004 & 0,160 & 3.381 & 0,001 \\
\hline Moderasi 4 (PKC x PKC) & 0,006 & 0,287 & 4.866 & 0,000 \\
\hline$R$ Square & & & & 0,687 \\
Adjusted R Square & & & & 0,682 \\
F-Test & & & & 134.717 \\
Probability & & & & 0,000 \\
\hline
\end{tabular}

a. Dependent Variable: Kualitas Laporan Keuangan

b. Predictors: (Constant), Moderasi 1 (KSDM x PKC), Moderasi 2

(PSAP x PKC), Moderasi 3 (PTI x PKC), Moderasi 4 (PKC x PKC)

Sumber data kuesoiner, diolah dengan aplikasi SPSS V.24, (2019)

Tabel.3 diatas menunjukkan hasil pemoderasi Pencegahan Kecurangan (Z) terhadap variabel Kualitas Laporan Keuangan. Output hasil pengujian diformulasikan dalam regresi berganda dari pengujian tabel 2 sebagai berikut :

\section{$\mathrm{Y} 2=\beta 0+\beta 1 \mathrm{Z1}+\beta 2 \mathrm{Z2}+\beta 3 \mathrm{Z3}+\beta 4 \mathrm{Z4}+\varepsilon$}

\section{$\mathrm{Y} 2=-0,966+0,005 \mathrm{KSDM}+0,279 \mathrm{PSAP}+0,087 \mathrm{PTI}+0,189 \mathrm{SPI}+0,488 \mathrm{PKC}+\varepsilon$}

Z1 Variabel Moderasi 1 (KSDM x PKC) memiliki koefisien parameter 0.000 tidak berpengaruh signifikan terhadap kualitas laporan keuangan, pada tingkat $0,05(0,840>0,05$, tingkat kepercayaan 95\%), artinya iteraksi variabel moderasi tidak memiliki pengaruh terhadap kualitas laporan keuangan, sehingga disimpulkan sehingga bahwa variabel pencegahan kecurangan bukanlah sebagai pemoderasi hubungan antara kualitas sumber daya manusia terhadap kualitas laporan keuangan.

Z2 Variabel Moderasi 2 (PSAP x PKC) memiliki koefisien parameter 0,011 dan berpengaruh signifikan terhadap kualitas laporan keuangan, pada tingkat $0,05(0,000>0,05$, tingkat kepercayaan $95 \%$ ), artinya iteraksi variabel moderasi memiliki pengaruh terhadap kualitas laporan keuangan, sehingga disimpulkan bahwa variabel pencegahan kecurangan sebagai pemoderasi hubungan antara kualitas sumber daya manusia terhadap kualitas laporan keuangan, iteraksi variabel disebut sebagai Quasi Moderator, artinya variabel pemoderasi pencegahan kecurangan memperkuat atau meningkatkan pengaruh penerapan standar akuntansi pemerintahan terhadap kualitas laporan keuangan sebesar $11,1 \%$.

Z3 Variabel Moderasi 3 (PTI x PKC) memiliki koefisien parameter 0,004 dan berpengaruh signifikan terhadap kualitas laporan keuangan, pada tingkat $0,05(0,001>0,05$, tingkat kepercayaan 95\%), artinya iteraksi variabel moderasi memiliki pengaruh terhadap kualitas laporan keuangan, sehingga disimpulkan bahwa variabel pencegahan kecurangan sebagai pemoderasi hubungan antara penerapan teknologi informasi berbasis sistem informasi 
akuntansi permerintahan terhadap kualitas laporan keuangan, iteraksi variabel disebut sebagai Quasi Moderator, artinya variabel pemoderasi pencegahan kecurangan memperkuat atau meningkatkan pengaruh penerapan teknologi informasi terhadap kualitas laporan keuangan sebesar 4\%.

Z4 Variabel Moderasi 4 (SPI x PKC) memiliki koefisien parameter 0,006 dan berpengaruh signifikan terhadap kualitas laporan keuangan, pada tingkat $0,05(0,000>0,05$, tingkat kepercayaan 95\%), artinya iteraksi variabel moderasi memiliki pengaruh terhadap kualitas laporan keuangan, sehingga disimpulkan bahwa variabel pencegahan kecurangan sebagai pemoderasi hubungan antara sistem pengendalian internal terhadap kualitas laporan keuangan, iteraksi variabel disebut sebagai Quasi Moderator, artinya variabel pemoderasi pencegahan kecurangan memperkuat atau meningkatkan pengaruh sistem pengendalian internal terhadap kualitas laporan keuangan sebesar $4 \%$.

\section{REKOMENDASI DAN KEBIJAKAN}

\section{Rekomendasi}

Berdasarkan hasil penelitian dengan interpretasi, maka peneliti memberikan kesimpulan, antara lain :

1. Hasil penelitian menunjukkan bahwa variabel independen memiliki berpengaruh terhadap pencegahan kecurangan antara lain : kualitas sumber daya manusia berpengaruh signifikan sebesar $11,5 \%$. penerapan standar akuntansi pemerintahan berpengaruh signifikan sebesar 28,8\%. pemanfatan teknologi informasi berpengaruh signifikan sebesar $6,7 \%$ dan Sistem pengendalian Internal (SPI) berpengaruh signifikan sebesar 4,40\% terhadap pencegahan kecurangan akuntansi.

2. Variabel independen memiliki berpengaruh terhadap kualitas laporan keuangan antara lain : penerapan standar akuntansi pemerintahan berpengaruh signifikan sebesar 27,9\%. pemanfatan teknologi informasi berpengaruh sebesar $8,7 \%$. sistem pengendalian internal berpengaruh signifikan sebesar $18,9 \%$ dan pencegahan kecurangan berpengaruh signifikan sebesar 4,88\% terhadap kualitas laporan keuangan.

3. Variabel pemoderasi 2 (Z2) sebagai pemoderasi memperkuat pengaruh penerapan standar akuntansi pemerintahan terhadap kualitas laporan keuangan sebesar 11,1\%. Pemoderasi 3 (Z3) sebagai pemoderasi memperkuat pengaruh penerapan teknologi informasi terhadap kualitas laporan keuangan sebesar 4\% dan Variabel Moderasi 4 (Z4) sebagai pemoderasi memperkuat atau meningkatkan pengaruh sistem pengendalian internal terhadap kualitas laporan keuangan sebesar $4 \%$.

\section{Kebijakan}

Pengendalian kecurangan akuntansi pada pemerintah daerah atas pengguan anggaran perlu dilakukan dan diterapkan melalui beberapa faktor yang mempengaruhinya, antara lain : peningkatan kompetensi sumber daya manusia bidang akuntansi dan keuangan/bendahara, penerapan sistem akuntansi keuangan daerah dengan baik, penggunakan apalikasi sebagai sistem informasi akuntansi keuangan daerah dalam menyusun laporan keuangan, pemanfatan teknologi informasi dalam memproses transaksi dan penyusunan laporan keuangan daerah, penegasan sistem pengendalian internal, hal ini dapat digunakan untuk mencegah kecurangan (fraud) menyusun lapaoran keuangan. 


\section{DAFTAR PUSTAKA}

Fadilah, Sri. 2011. Pengaruh Implementasi Pengendalian Internal dan Komitmen Organisasi dalam Pencegahan Fraud Pengadaan Barang (Survey pada 5 Rumah Sakit di Bandung). Universitas Widyatama Bandung

Indonesian Corruption Watch. 2017. Laporan Pengendalian Intern dan Total Quality Management Terhadap Penerapan Good Governance (Studi pada Lembaga Amil Zakat Seluruh Indonesia). Simposium Nasional Akuntansi XIV. Universitas Syiah Kuala, Banda Aceh.

Hermiyetti. 2008. Pengaruh PenerapanPengendalian Internal terhadap Pencegahan Fraud Pengadaan Barang. STEKPI Jakarta.

Purwitasari, Anggit. (2013). Pengaruh

ahunan ICW 2016. Diakses, 25 Januari 2019, dari http://www.antikorupsi.org/

Lediastuti, D., dan U. Subandijo. 2014. Audit Forensik Terhadap Pengelolaan dan Pertanggungjawaban Keuangan Negara (Studi Kasus pada Badan Pemeriksa Keuangan RI). e-Journal Magister Akuntasi Trisakti Volume 1 No.1: 89-108

Manik, Tumpal. 2018. Analisis Peranan Sistem Informasi Akuntansi Dalam E-Commerces Terhadap Pengendalian Bisnis Online, Jurnal IImiah Akuntansi dan Finansial Indonesia Volume 1, No.2, April Hal. 51- 64, Fakultas Ekonomi Universitas Maritim Raja Ali Haji, Tanjungpinang

Martani, Dwi., \& Fazri Zaelani. 2011. Pengaruh Ukuran, Pertumbuhan, dan Kompleksitas terhadapPengendalian Intern Pemerintah Daerah (Studi Kasus di Indonesia). Simposium Nasional Akuntansi XIV. Universitas Syiah Kuala, Banda Aceh.

Nisak, Chairun., Prasetyono \& Fitri Ahmad Kurniawan. 2013. Sistem Pengendalian Intern dalam Pencegahan Fraud pada SatuanKerja Perangkat Daerah (SKPD) pada Kabupaten Bangkalan. JAFFA, 1(1), $15-22$.

Permana, BA., HD. Perdana., dan L. Kurniasih. 2017. Determinant of Fraud in Government Agency: Empirical Study At The Finance And Development Supervisory Agency (BPKP) Of Jakarta Representative Office. Asia Pasific Fraud Journal Volume 2 No.1: 93-108. doi:10.21532/apfj.001.17.02.01.08.

Surjandari, DA., dan I. Martaningtyas. 2015. An Empirical Study: The Effect of Performance Incentives, Internal Control System, Organizational Culture, on Fraud of Indonesia Government Officer. Mediterranian Journal of Social Sciences, Volume 6 No.5: 71-76.doi: 10.5901/mjss.2015.v6n5s5p71

Tuanakotta, Theodorus M. (2012). Akuntansi Forensik dan Audit Investigatif. Penerbit: Salemba Empat.

Tuanakotta, Theodorus M. 2014. Mendeteksi Manipulasi Laporan Keuangan, Penerbit: Salemba Empat : Jakarta

Setyowati, Lilis dan Wilkan Isthika. 2014. Pengaruh dampak peranan sistem informasi akuntansi keuangan daerah, pemahaman akuntansi, kompetensi sumber daya manusia, serta peran internal audit terhadap kualitas laporan keuangan daerah pada pemerintah Kota Semarang (Studi pada SKPD Kota Semarang). Universitas Dian Nuswantoro, Semarang

Tri, Novia, Anna Fariyanti dan Nirwan Ristiyanto. 2018. Strategi Pencegahan Kecurangan (Fraud) Dalam Pengelolaan Keuangan Pemerintah. Jurnal Manajemen Pembangunan Daerah. Volume 10 Nomor Khusus, April 2018. 